\title{
THE INFLUENCE OF FRIEDMAN'S METHODOLOGICAL ESSAY
}

\section{THOMAS MAYER *}

Many leading methodologists have described the central role that Milton Friedman's 1953 essay (henceforth referred to as F53) has played in methodological discussions. (See for instance Daniel Hammond, 1998; Kevin Hoover; 2001; Roger Backhouse 2002.) However, it does not necessarily follow that it has had a great influence on the practice of economics, because practicing economists pay little attention to free-standing discussions of methodology; at best they learn their methodology by seeing it put to work on substantive problems. ${ }^{1}$ Arguably, Friedman and Schwartz's (1963) A Monetary History of the United States, has had more influence on the methodology of practicing economist than did F53. The most pervasive methodological influence in macroeconomics in the last thirty years has been the insistence of new classical economists on reducing macroeconomics to microeconomics, and in this they paid no attention to philosophical debates about reductionism

Friedman did not intend his essay to be a contribution to methodology, about which he did not claim any expertise, but to be only a description of the approach he found useful in his practice. For that his failure to clarify whether he is an instrumentalist, falsificationist or whatever - the issue on which methodologists have focused - is unimportant. (See Hirsch and de Marchi, 1990, p. 80). I deal only with F53's effect on his intended audience, practicing economists, and discuss almost only mainstream economists. Heterodox economists have been highly critical of F53, so that it is unlikely to have had much influence on them. I also omit its influence on econometrics (for that see Hoover, 2003) and on government and business economists, since their work is almost invisible to other economists. Other essays in the book containing F53 also discuss 
methodology. If these discussions relate to ideas discussed in F53 I treat them as part of it, but refer only occasionally to methodological claims that Friedman made elsewhere, Before seeing how F53 has influenced economics let us look at its message (Section I), at some difficulties in evaluating its influence (Section II), and at the reviews it initially received (Section III). Due to limitations of space - and knowledge - I limit the discussion to a survey of (a) three general trends in economics: formal modeling, game theory, and econometric testing. (Section IV); (b) Nobel lectures (Section V); and (c) certain topics in macroeconomics (Section VI). This emphasis on macroeconomics is not based on any deep principle, but only on my greater familiarity with it. I end the discussion of macroeconomics with the new classical counterrevolution, because the further one goes beyond 1953, the greater is the probability that a change advocated in F53 is due to some other influence. But I discuss Nobel prizes up to 2002 because of the lag until work is recognized by the Nobel Committee. ${ }^{2}$

\section{FRIEDMAN'S THEMES}

F53 has one general and six specific themes. The former is the desirably of combining theoretical and empirical work, and thus to heal the split between theorists and institutionalists, to whom Friedman is closer than is often appreciated (see Friedman, 1949, 1950). He was, of course, not the only one who attempted this. It was a general trend that would eventually have prevailed even in his absence. However, what has dominated the discussion is F53's specific theme that hypotheses should be not be tested by the realisticness of their assumptions. A second theme of F53 is the superiority of Marshallian over what Friedman calls "Walrasian" economics. This created a terminological problem. As Hutchison 1954) pointed out the latter does not represent Walras' own views on methodology. Nor does it necessarily represent the methodology of those using a general equilibrium approach; we now have computable general equilibrium 
models. But Friedman's terminology has caught on, so rather than the more appropriate term "formalistic" I will use Friedman's term, but with a lower case "W" to mark the misuse of Walras' name. The third theme is the rejection of introspection and other forms of casual empiricism, and the fourth is the distinction between normative and positive economics. A fifth theme, relating to the context of discovery, is the benefit of a continual interplay of attention to data and to theory construction. A final theme is the need for modesty about what economic theory can accomplish. This theme (which deserves a paper of it own, since it underlies most of Friedman's other themes and some of his substantive work) is not well articulated and usually ignored, so, I too, will ignore it. ${ }^{3}$

\section{Realisticness of Assumptions}

Friedman's claim that hypotheses should not be judged by the realisticness of their assumptions but by the predictive success of their implications does not seem so startling once one recognizes that F53 still allowed testing by the realisticness of critical assumptions, since these can be rephrased as implications (see Baumol, 1954, Mayer, 1995, Ch. 7). ${ }^{4}$ If Fried man's objection to testing hypotheses by the realisticness of their assumptions is so much less startling than it appears at first glance why did it almost monopolize the discussion? Likely reasons include that he stated it with much elan and at much greater length than his other themes, its wide scope and its seeming conflict with intuition. Moreover, it was seen as a massive salvo in the ongoing battle about neo-classical theory. And, while practicing economists might applaud Friedman's deep insight into how economists work, for methodologists Friedman's philosophically amateurish exposition, combined with his high status in the profession, made F53 a tempting target, and the assumptions issue seemed a weak spot.

2. Marshallian Intuition vs. Walrasian Rigor 
Many economists have (wrongly) read Friedman's objection to testing by the realisticness of assumption, not as an argument for testing by predictive success, but as enhancing the importance of three other criteria for theory choice, elegance, generality and rigor, and hence as supporting their insistence on formal derivation of hypotheses from explicitly stated assumptions. So, assumptions again play a key role. But what matters now is not their realisticness, but their congruity with the canonical assumption of rational profit maximization, as well as their parsimony. But that is not Friedman's criterion for theory choice.

The only relevant test of the validity of a hypothesis is comparison of its predictions with experience. ... Logical completeness and consistency are relevant, but play a subsidiary role; their function is to ensure that the hypothesis says what it is intended to say. ... One of the effects of the difficulty of testing substantive economic hypotheses has been to foster a retreat into purely formal or tautological analysis. ... [T] autologies have an extremely important role in economic analysis. ... But economic theory must be more than a structure of tautologies ... if it is to be something different from disguised mathematics. (Friedman, 1953, pp. 8-12, italics in original)

Friedman paid much attention to the shortcomings of such "disguised mathematics"

masquerading as economics. In F53 he referred readers to another chapter of the book, a review of Oscar Lange's Price Flexibility and Employment, where he wrote:

Here is a brilliant display of formal logic, abstract thinking, complicated chains of deductions, yet the analysis seems more nearly a rationalization of policy conclusions previously reached than a basis for them. What is there about the type of theorizing employed that makes it sterile ... ? The basic sources of the defects ... are the emphasis on formal structure, the attempt to generalize without first specifying in detail the facts to be generalized, and failure to recognize that the ultimate test of the validity of a theory is not conformity to the canons of formal logic but the ability to deduce facts that have not yet been observed, that are capable of being contradicted by observation, and that subsequent observations do not contradict. (Fried man, 1953, pp. 277 and 300)

Elsewhere in the book Friedman (pp. 112-13) wrote that: "formal analysis can seldom if ever give easy answers to hard problems. Its role is quite different: to suggest the considerations 
relevant to an answer and to provide a useful means of organizing the analysis." And in his discussion of the Marshallian demand curve Friedman (p. 91) told us that:

The test of the theory is its value in explaining facts, in predicting the consequences of changes in the economic environment. Abstractness, generality, mathematical elegance -- these are all secondary, ... Doubtless, most modern economic theorists would accept these general statements... . But our work belies our professions.

Abstractness, generality and mathematic elegance have in some measure become ends in themselves, criteria by which to judge economic theory. ${ }^{5}$

Hammond (1990) considers Friedman's rejection of formalism a more important component of

F53 than rejection of testing by the realisticness of assumptions, and calls "Marshallianism" the "hallmark of Friedman's methodology." (Hammond, 1996, p. 43)

\section{Casual Empiricism and Introspection}

Friedman's belief that appearances may be misleading, and his resulting criticism of casual empiricism and introspection, is set out in more detail in his review of Lange than in F53 ${ }^{7}$. There he showed that Lange's analysis is a deductive system that requires certain assumptions that are just unverified conjectures. To Friedman such casual empiricism is insufficient. And though he did not mention this, this theme supports his insistence on testing implications rather than assumptions since many assumptions can only be tested casually. ${ }^{8}$ Along with rejecting casual empiricism he also rejected reliance on the responses of firms to questions about what they do and why.

\section{Normative and Positive Economics}

F53 claimed that the normative/positive distinction has received inadequate attention, and conjectured that disagreements on economic policy among disinterested people in the West are primarily disagreements about positive issues. But Friedman also subtracted something from previous discussions by ignoring a third category of economics, J. N. Keynes' (1891) art of 
economics, that is the knowledge required to apply positive and normative economics in a way that results in successful policies. (See Colander, 1991.) This is surprising since in his chapter reviewing Abba Lerner's Economics of Control Friedman castigated Lerner for ignoring problems pertaining to the art of economics. Also, Friedman lacked the postmodernists' nose for any whiff of normative elements,

\section{Interplay of Theory and Observation}

Friedman's fifth theme concerns the process of discovery. He advised against developing theory after a merely casual acquaintance with the data, and also against just concentrating on the data, and either being satisfied with mere description, or else expecting theory to spring from the data like Athena from the head of Zeus. This "interplay" theme characterizes Friedman's own

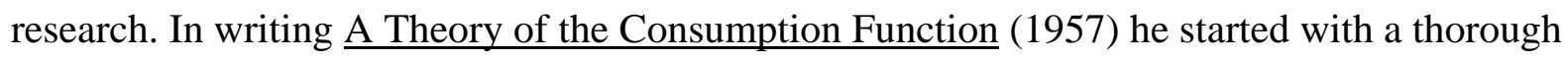
knowledge of the data. In his monetary theory he carefully combined theory with his empirical evidence. The primary reason A Monetary History of the United States (1963) has been so influential is the masterly way it combines detailed knowledge of historical facts with an overarching theory.

\section{SOME DIFFICULTIES IN ESTIMATING THE INFLUENCE OF F53}

Several major difficulties arise in gauging the influence of F53. First, suppose that in its absence some other methodology, such as operationalism, had taken over. If, so then F53 had a great, but hidden, influence. Second, what economists write might not accurately reflect how they act or what motivates them. ${ }^{7}$ Thus, F53 may prevent an economist from writing a paper criticizing a model for its assumptions, and yet she may still not accept it because of these assumptions. Third, in the absence of F53 someone else might have written a similar and just as influential 
paper. There is nothing that can be said about this, except that a similar thing is true of Darwin. So, I will ignore it.

Fourth, the influence of a methodological paper is often subtle and more difficult to detect than the influence of other papers. Suppose an economist who in 1935 analyzed inflation in terms of the money supply and its velocity, analyzed it in 1937 in terms of the marginal efficiency of capital. The influence of Keynes is obvious. And when economists use unit root tests Granger's influence is clear. But the influence of F53 may be less obvious; Marshallian or walrasian outlooks are a matter of emphasis, and since F53 allows testing by assumptions that are also implications, not every test by the realisticness of assumption shows a lack of influence of F53. Nor is every instance of unconcern about the realisticness of assumptions due to F53. Another difficulty is inferring causation from correlation. Economics may have evolved in ways advocated in F53, but primarily for other reasons. These include (a) economists' increased mathematical skills; (b) the revolution in data analysis due to computers, new econometric techniques and greater availability of data; (c) an increase in the funding and volume of academic research; and (d) the increased role of economists in policy- making; (e) the greater prestige of Chicago economics (which is in part endogenous to F53), and (f) an apparent improvement in the intellectual quality of economists, probably due largely to improved academic salaries. Table 1 summarizes the likely effects of these factors for all of Friedman's themes, except the confounding of positive and normative economics, a point at which economics has not changed much.

The increased use of mathematics (apart from its effect through econometrics) has had conflicting effects for F53. It increased formal modeling which often requires tolerance for many unrealistic assumptions. But it also encouraged a shift away from the empiricism and from the 
emphasis on predictive success that underlies Marshallian economics. This decreased emphasis on genuine empiricism may perhaps also have resulted in an increase in casual empiricism, and by emphasizing theory might have reduced the interplay of theory and data.

The revolution in data analysis obviously stimulated Marshallian empirical work. It also made it much easier to evaluate predictive success, but had less effect on the ability to test the realisticness of assumptions, so that it shifted emphasis towards the former. ${ }^{8}$ It also reduced the reliance on casual empiricism and introspection. ${ }^{9}$ Its effect on the interaction between theorizing and data analysis is ambiguous. There is an obvious positive effect, but the ease with which one can now test a hypothesis, and if the data reject it, quickly formulate and test another version, has reduced the pressure to re-think one's theories when the data do not oblige, and this reduces the effectiveness of theory and data interaction. ${ }^{10}$

The resources devoted to economic research have increased dramatically. By 1953 in the U.S. the shift in the self-image of faculty members from that of learned gentlemen enjoying consider able leisure to that of harried researchers had not yet run its full course, resources, such as research assistants, were scare and universities were fewer and smaller. With increased resources and numbers came an increased professionalization, and thus a greater belief that economics is an autonomous subject and not just one of the social sciences. Hence, economists no longer had to be so concerned if their assumptions seemed bizarre to other social scientists and to the public, or even to themselves - there is safety in numbers. While Irving Fisher may have worried about how the assumptions he made in his books would strike the general reader, this is of no concern to someone publishing in Econometrica. Increased professionalization also favored walrasian economics as economists focused more on acclaim from fellow economists rather than the general public. Walrasian economics with its claims of rigor and elegance has relatively more 
appeal to a self-absorbed profession that claims to be "scientific", while Marshallian economics has more appeal to those who address the concerns of a broader public. On the other hand, it is quite possible that with the expansion of the profession the opportunity for any particular economists to make an even arguably worthwhile contribution to abstract theory has declined, and hence Marshallian empirical work has filled the gap. A rise in the ratio of research assistants to faculty researchers could also shift research in an empirical direction, but with falling teaching loads and increased pressure to do research, it is not clear that this ratio has risen. The net effect on Marshallian versus walrasian economics is therefore unclear.

Increased resources have reduced the need to for casual empiricism and introspection. But their effect on the interplay of theorizing and data analysis is unclear. On the one hand, they have facilitated the use of statistical data, but on the other, increased professionalization has reduced the use of observations in the form of reality checks provided by personal every-day experience, which could now be dismissed as "mere anecdotes".

The greater role that economists now play in policy-making may perhaps have led them to stress predictive success more than realisticness of assumptions, and it surely led them to prefer Marshallian to walrasian theory. But, given the lack of information required for many policy issues, and the pressure to come up with answers (and sometimes with answers pleasing to policymakers), it may have increased reliance on casual empiricism. Also, it has probably increased the interplay of data and theory since that is helpful in dealing with applied problems. In the period following Friedman's paper the prestige of the Chicago economics department rose as its members gathered a disproportionate share of Clark medals and Nobel prizes (see Reder, 1982), and as more of their substantive work appeared. That economists tended to view markets more favorably also helped. This probably enhanced the standing of all of Friedman's work, 
including F53. This leaves the higher intellectual caliber of entrants into the profession.

Supporters of Friedman's themes surely believe that this facilitated their acceptance, while their opponents believe the opposite.

Table 1 summarizes these influences. Only on the assumptions/predictions issue (and perhaps on the casual empiricism issue) did all the changes, with the possible exception of the increased quality of economists, favor F53. On the other issues it is unclear whether the prevailing winds favored or hindered the acceptance of F53. Hence, it is possible that its apparent success was due less to its persuasive power than to good luck. But one also cannot just dismiss the opposite idea that, except on the issue of realisticness of assumptions, its successes were won in the face of strong headwinds. This is an unsatisfactory conclusion, but when dealing with causality unsatisfactory conclusions are hardly rare.

A final issue on causality is overdetermination. Were Fried man's themes "in the air" at the time? There is no evidence for this, neither in the reviews of F53 nor in the initial responses of methodologists. While Terence Hutchison and Fritz Machlup, shared some of Friedman's ideas, that is not the same as these ideas being "in the air." And Hutchison and Machlup lacked Friedman's persuasive powers.

\section{REVIEWS OF F53}

Essays in Positive Economics was reviewed in The American Economic Review, The Economic Journal, The Economic Record, Economica, The Review of Economics and Statistics, The $\underline{\text { Southern Economic Journal and the Weltwirtschaftliches Archiv, Surprisingly the Journal of }}$ Political Economy did not review it. Nor did The Canadian Journal of Economics and Politics, The Indian Journal of Economics, The Journal of the American Statistical Association. Kyklos, 


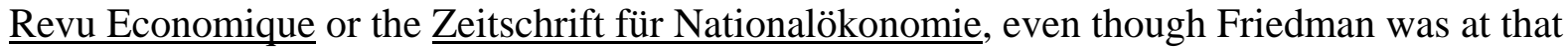
time already well-known, having won the Clark medal two years earlier. ${ }^{11}$ William Vickrey (1954) commented extensively on the book's macroeconomic chapters, while not mentioning F53 at all, and dismissed the chapter criticizing Lange in one sentence. But William Baumol (1954, p. 465) called the book: "certainly one of the most engrossing volumes that has appeared recently in economic theory", and devoted about one fifth of his review to F53. (It accounts for 13 percent of the book). He called it "highly stimulating" (p. 464), even though "it rides hard on a single point", and fails to present Friedman's viewpoint systematically (p. 463). In particular, while it seems to suggest that economists should seek only correlations, even if they are spurious, he believed that Friedman said something much more acceptable that "badly needs saying" (p. 465), because he permitted testing by assumptions - if these assumptions can be reformulated as implications. While agreeing with the essence of Friedman's argument he nonetheless objected to accepting a hypothesis that has ridiculous assumptions, because we should ask whether it abstracts in a way that omits aspects important for the problem at hand. Peter Newman (1954) called the book "an enjoyable feast, though perhaps some readers should be warned to take it "cum grano salis, ... stimulating, provocative, often infuriating, but well worth reading." (pp. 259 and 260, italics in original) Only two and a half sentences of his one and a quarter page review dealt with F53. He referred to testing hypotheses by predictive success instead of realisticness of assumptions as "salutary and rewarding principle too far. Hutchison (1954) described the book as containing so "much that is acute, independent and stimulating", that though "there is much to disagree with ... this collection of essays should be widely and warmly welcomed." (p. 799) Almost half his review dealt with Friedman's methodology, both in F53 and in other chapters. He did not mention Friedman's strictures against 
testing by the realisticness of assumptions, though he did discuss his insistence on tested by predictive success. Also, unlike most reviewers, he also dealt with other aspects of Friedman's methodology, such as Friedman's emphasis on the distinction between normative and positive economics and his complaint against the prevailing overemphasis on elegance, generality and taxonomy.

Clark Allan (1954) called it "a collection of remarkable essays" (Allan, p. 394) that refutes claims that neo-classical theory is of no use to policymakers. And "what is profoundly more significant" (p. 394), it shows that in some areas where we thought we had unequivocal knowledge, we do not. In discussing F53 Allen summarized Friedman's criticism of testing by the realistic ness of assumptions, but did not go beyond that. C. S. Soper (1954) devoted about a third of his review to F53, summarizing Friedman's belief that most disputes among economists concern positive issues, and also his rejection of testing by the realisticness of assumptions. While he mostly just summarized F53, he also argued that Friedman, by stressing that a theory's predictions can only be tested for the phenomena it seeks to explain, fails to tell us how to enlarge its sphere of validity. In his two paragraph review Erich Schneider (1955) dispatched F53 in two sentences, saying that Max Weber and Joseph Schumpeter will already have familiarized German readers with its contents, but even so, that the clarity of Friedman's presentation makes it enjoyable reading. ${ }^{12}$ In summary then, four of the seven reviews of F53 were laudatory, one can at best be described as mixed, another was dismissive, and one made little attempt at evaluation. None predicted its future importance. Nor did the decision of many journals not to review Friedman's book suggest a brilliant future for it. And only one reviewer, Hutchison, was able to see sufficiently beyond the realisticness-of-assumptions issue to discuss at some length Friedman's criticisms of 
empirically inapplicable formalism, perhaps because that resembled his own position. But the reviews did have a commendable characteristic; while casual observation suggests that many economists treated F53 as an apologetic for neo-classical price theory, none of the reviewers took that line.

\section{AN OVERVIEW}

Friedman's underlying theme - combine theoretical and empirical work by focusing on predictive success - carried the day and the relative importance of empirical work has increased (see Figlio, 1994, Hoover 2003). By no means all of the credit here belongs to Friedman. Thus, James Duesenberry (1949) had previously published an outstanding example of such work, which I was told had much influence on Harvard students. From outside of economics there was the influence of Popper and of positivism in general. Other social sciences moved in the same direction. But surely Friedman deserves some of the credit, if only because he furnished neo-classical economists with a defense against their institutionalist critics, thus giving economic theory some breathing room, while commending the use of data to test theories rather than just to compile facts.

But the subsequent decline of old-line institutionalism should not be entirely (or even largely ?) be attributed to Friedman. The rise of econometrics also played a part. One could now be an empiricist in a more glamorous way than by just gathering data - if one could manage the required math. And since many institutionalists could not, they had to relinquish their claim to be the shining example of the empirical and hence "scientific approach" to economics. The increased professionalization of economics with its tendency to draw sharp disciplinary lines also played a role since it meant that the preoccupation of some institutionalists with sociological and historical problems tended to place them outside the limits of economics. All the same, it 
seems plausible that Friedman's essay significantly and perhaps even substantially contributed to the decline of institutionalism; perhaps, given his tribute to Mitchell (Friedman, 1950) by more than he wished.

Contemporary academic economics consists primarily of modeling exercises, particularly in game theory (discussed in Appendix A), and in exploring the implications of asymmetric information. Some of these models try to earn their keep by eliminating assumptions made in previous models. But they do this to generalize them, and not to criticize them for unrealisticness. That "all models are false, but some are useful," has become a familiar cliché. Granted that occasionally economists criticize a paper for its unrealistic assumptions (see, for instance, Waldman, 1993), this is consistent with F53 if these assumptions are also a relevant implications.

But Friedman's victory is incomplete. While most economists no longer explicitly reject some model for its unrealistic assumptions, they may still (perhaps unconsciously) be unwilling to accept it for that reason. And much more seriously, Friedman's stricture that the implications of models need tough-minded testing is often ignored. Tests of implications are often perfunctory, "playing tennis with the net down" (Blaug, 1980, p. 256). Friedman has been much less persuasive on the superiority of Marshallian economics. While most empirical work is Marshallian, within theory the walrasian approach has become more common since 1953. But only a small proportion of papers are purely theoretical, so that the vaunted victory of walrasian economics is more a matter of Sunday dress than workday dress. But it is to the profession's Sunday dress that many (most) economists point with pride. Casual empiricism is a pejorative term and, in principle, few economists would now explicitly defend it, but few would have done so in 1953 either. Whether the indifference curve between using casual empiricism and admitting 
ignorance has changed is hard to say. What has changed massively is the budget constraint.

Friedman has, however, been more successful in combating the Robbinsian emphasis on introspection, though it probably still plays a significant implicit role by excluding certain

models that do not make intuitive sense. It is hard to say whether the surveys of motives and beliefs that Friedman criticized are less frequent now. than before $1953 .{ }^{13}$

While postmodernism has had virtually no influence on main stream practicing economists, so that Friedman's dictum to separate normative from positive statements still holds sway, there is little reason to think that it is obeyed any better or worse now than before 1953. It is, however, likely that in theory construction there is now more interplay of theorizing and data analysis than before 1953.

\section{NOBEL PRIZE LECTURES}

Two considerations justify using Nobel lectures to characterize the way economics has changed. First, in economics Nobels are given, not for establishing indubitable results, but for initiating, or carrying to fruition. a particular sub-literature. They therefore highlight the growth points of economics. Second, the Nobel Committee largely represents the judgment of the profession. My sample consists of all Nobel lectures up to 2002 with the following exceptions: When several recipients split the prize I used the lecture of only one of them, chosen somewhat arbitrarily. I also excluded Klein, Tobin and Modigliani because I cover their work in the next section. Laureates have considerable latitude in their lectures. Most focus on their own work, or work that derives directly from it, but six did not, and are therefore excluded from the sample. ${ }^{14}$ Table 2 categorizes the remaining 22 lectures by 4 characteristics of F53. A plus denotes consistency with a characteristic, a minus inconsistency, and a zero the irrelevance of this characteristic. ${ }^{15}$ Such a classification is inevitably subjective and sometimes somewhat arbitrary - but then 
tracing the influence of a paper is more like doing literary criticism than like doing physics.

(Appendix B provides summary information on the included Nobel lectures.) While the minuses in Table 2 have a straightforward interpretation the pluses do not. They show only that the lecture conforms to a certain recommendation of F53, and not necessarily that F53 influenced it. For example, someone who tests a hypothesis by its implications may do so only because in this case it is quicker than testing by the realisticness of assumptions.

What is remarkable in Table 2 is the paucity of minuses. If the Nobel committee's judgment is correct few of the outstanding breakthroughs came from those employing a methodology contrary to F53. On the issue of assumptions versus predictions there are 11 pluses, and only 4 minuses, while on the Marshallian/walrasian dichotomy there are 16 pluses and 4 minuses. On the rejection of casual empiricism there are 15 pluses and 1 minus. And on the interplay of data and theories 12 pluses confront 2 minuses. Such a tabulation is subject to the criticism that I followed the naive empiricist's bad advice of: "go measure something, never mind what it is." In depicting the thrust of mainstream economics some prizes (e.g. Samuelson's) may deserve more weight than others. Indeed, it seems obvious that the frequencies in Table 2 shortchange the formalist trend in economics. With only 4 of the 23 of the prizes going to formalists (Samuelson, Arrow, Debreu and Harsanyi) the influence of formalism is surely understated.

\section{MACROECONOMICS}

This sections deals with the three major macro research programs, Keynesian, monetarist, and new classical. It omits the Austrian and post-Keynesian programs because they are heterodox, and new Keynesian theory, and endogenous growth theory, because they came too late.

\section{The Keynesian Program}


The major components of the traditional Keynesian program are the consumption function, the investment function, a general equilibrium version of monetary theory, econometric models, and growth theory. All are positive theories that do not introduce normative elements to a greater extent than is usual in economics.

\section{i. The Consumption Function}

Here the most important breakthrough was the permanent income theory (PIT) of Friedman (1957) and the closely related life cycle hypothesis (LCH) of Modigliani and associates, followed by Hall's reformulation of these theories in a rational-expectations framework. All three followed F53 in judging their hypotheses by their predictive success and not by the realisticness of their assumptions. Specifically, they assumed intertemporal utility maximization even over long horizons. They also assumed (though Modigliani did so only tentatively) that the savings/income ratio is uncorrelated with permanent income. They did not justify these assumptions as realistic, but instead tried to show that their theories predicted consumption accurately and resolved some puzzling anomalies.

These theories are Marshallian in treating income as exogenous. A more walrasian approach would use as the budget constraint, not permanent income, but the household's potential labor supply multiplied by the wage rate, plus nonhuman wealth. They also avoid the casual empiricism and introspection on which Keynes relied when he grounded his consumption function in: "The fundamental psychological law upon which we are entitled to depend with great confidence, both a priori from our knowledge of human nature and from the detailed facts of experience," (Keynes, 1936, p. 96, italics in original.) Friedman (1957, p. ix) who stated that he developed his theory from a close study of the data gives the strong impression of an interplay of data and theory. This is less so for Modigliani. ${ }^{16}$ 


\section{ii. Investment}

In the two decades after 1953 the two most notable developments here were Dale Jorgenson's neo-classical theory and James Tobin's q theory. The former is based on two insights: that earlier work on investment had confounded the capital stock and investment (its first derivative), and the need to pay attention to the institutional details of the tax treatment of investment. The latter is based on the gap between the market price of new capital and its costs of production. Neither is easy to trace to F53. Jorgenson's theory appeared fourteen years after F53. Its attention to the distinction between capital and investment is a clarification of the internal logic of the theory, and hence unrelated to F53. The inclusion of tax variables may seem to show concern about the realisticness of assumptions. But Friedman did not object to adding realistic details if they improve predictive success. Tobin's q theory, too, appeared only long after F53. Since it does not attempt to explain the firm's equity price it is more a tool for predicting investment than an explanatory theory. An instrumentalist reading of F53 would therefore make it seem

Friedmanian, but as the Mäki and Hoover papers in this volume show such a reading is mistaken. Both theories are Marshallian in that they focus on a concrete problem rather than on elegant formulations. Developing them may well have involved a close interplay of theory and data; no information on this is available.

\section{iii. Monetary and Portfolio Theories}

The most influential Keynesian monetary theory is that of Tobin and his Yale school. It takes account of the complexity of the financial system, with money being just one asset in a continuum of liquid assets. Such an approach rejects F53. It seeks to give a realistic picture of the financial system, and does not stress prediction. It is also walrasian. And Tobin gives the impression that he relied on broadly based observations (akin to casual empiricism), such as 
Treasury bills having characteristics similar to money, rather than on a close interplay of theory and data.

\section{iv. Econometric Models of the Economy}

Although F53 was not published until three years after Lawrence Klein's (1950) initial model it could have influenced subsequent models. Or, if these models follow the methodology recommended in F53, that could account for their popularity, and hence document the influence of F53.

Predictive success, not the realisticness of their assumptions, is the main criterion by which these models ask to be judged. ${ }^{17}$ But that does not bear testimony to the influence of F53, because prediction is clearly their main purpose, even if one believes that scientific hypotheses should be judged by their assumptions. Although they are general equilibrium model. in Friedman's terminology they are Marshallian, because they seek to provide empirical and practical knowledge and make no claim to elegance. Casual empiricism may play a role in choosing their individual equations, but primarily they are chosen to accord with substantive empirical results. Their generation relies on a constant interplay of observation and theory. Indeed, one of the criticisms of these model is that they are over-fitted.

\section{v. Growth Models}

In the early 1960s the first wave of growth theory accounted for a substantial part of the work in macroeconomics. Much of it consisted of varying some previously made assumptions. It essentially stopped after a critical survey by Frank Hahn and Robbin Matthews (1964) who wrote:

The variety of growth models is very great and with ingenuity can evidently be almost indefinitely enlarged. This is very largely due to the rather extreme level of abstraction employed and the very artificial nature of the problems considered. ... We want theories that can be used as 
plumbers use a spanner - not simply abstract systems" ,... It would be difficult to claim that any of the models we have discussed goes far towards explaining ... [the observed differences in growth rates of countries and periods]. (Hahn and Matthews 1964, pp. 888-90.)

Clearly, these models are contrary to F53. Whether Hahn and Matthews were influenced by F53 (which they did not cite) is hard to say, as is whether the apparently widespread acceptance of their conclusion owes much to F53.

\section{Monetarism}

F53 provided monetarists with a battering ram for their assault on the prevailing Keynesian orthodoxy, At that time the wealth effect of falling interest rates on consumption was little known, and with exchange rates being more or less fixed, the claim that changes in the money supply could substantially affect income appeared to require an (at that time) seemingly implausibly high interest elasticity of investment. Friedman's responded that while it would be desirable to trace the channels by which money affects income, this is not necessary. Instead, one can document numerous cases in which changes in nominal income had followed exogenous changes in money, and combine that fact with the general explanation from price theory, that when there is an exogenous increase in the supply of one asset (money) the demand for the other asset (goods) increases. The other leading variant of U.S. monetarism, the work of Brunner and Meltzer, too, emphasized testing by implications, even though they provided a fairly elaborate theoretical discussion. ${ }^{18}$

Without such a predictive orientation monetarism would not have achieved its popularity. Most economists would then have agreed with Frank Hahn's (1971, p. 61) objection that: "Friedman neither has nor claims to have a monetary theory. His strong and influential views are not founded on an understanding of 'how money works', but on what his empirical studies have led him to believe to have been the course of monetary history." In principle, it is obvious that the 
demand for money, and hence its velocity, depends upon the expected yields of all competing assets. Yet, unlike the Yale school, Friedman disregarded them because he believed that including them did little to improve the theory's predictions.

The monetarists' case is also bound up with their rejection of the mixture of introspection and casual empiricism that was a prominent part of then prevailing Keynesian thinking. Examples are Keynes' consumption function, his intuition that the main factors generating changes in GDP are changing expenditure motives rather than changes in the money supply, and the empirical significance of the speculative demand for money. To successfully challenge Keynesian theory monetarists had to show that what seemed commonsensical and intuitively obvious was an insufficient basis for macroeconomics. ${ }^{19}$

The need to distinguish sharply between normative and positive elements played little role in the debate. Although normative issues permeated policy discussions, both sides failed to draw sufficiently clear distinctions between normative and positive issues. Still another Friedmanian theme, the need for interplay between theoretical and empirical work may have played a substan tial role in the rise of monetarism, since it was well suited to what the monetarists were doing. Moreover, the monetarists' interplay of theory and empirical work may have made monetarism more popular by providing a welcome contrast to the bifurcation of much of the Keynesian research program between theorists who did not test their theories, and applied economists who focused on forecasting.

\section{New Classical Theory}

The substantive message of new classical theory, rapid market clearing, has won a foothold, but not a victory, But its methodological message, that is, its reductionist dogma, has. Despite Friedman's own rejection of new classical theory some economists credit (or blame) F53 for it, 
since it justifies the use of unrealistic assumptions, such as highly flexible wages. As Wade Hands' paper in this volume shows, within the science-studies dimension this is so, and the victory of new classical methodology documents the influence of F53. But it is more a defeat than a victory for Friedman, because the new classicals misuse F53. By insisting that discussions of macroeconomic phenomena make no assumptions that are not firmly grounded in microeconomics they treat assumptions as an integral and crucial part of the analysis, while to Friedman, assumptions are background scenery that can be varied, depending upon the play currently on stage. Moreover, when Friedman objected to testing by the realisticness of assumptions, he did not do so in favor of a priorism, but in favor of predictive testing. And, although the new classicals often present predictive tests, they give the impression that these tests are tagged on more for the sake of decoration than for the heavy lifting: "Theory ahead of observation" is their slogan. I conjecture that no economist has ever accepted rationalexpectations theory primarily because he or she found the empirical evidence convincing. On the issue of Marshallian versus walrasian economics, new classical economists are obviously not Friedmanian. It is unclear to what extent they adhere to his rejection of casual empiricism, in part, because using elaborate econometrics is no talisman against casual empiricism, and in part because it is unclear whether the estimates inserted into calibrated models are derived from an objective survey of the literature or selected because they happen to give results consistent with new classical theory. Friedman's insistence on distinguishing positive from normative elements is again not relevant. But the interplay between theory development and intimate knowledge of the data that Friedman recommends is relevant and it seems missing in new classical theory,

\section{SOURCES OF INFLUENCE}


Although, as previously discussed, several factors impelled economics in the directions advocated in F53 I believe (though I certainly cannot "prove") that F53 played a significant role in changing economics. One reason for this belief is the merit of its thesis. Methodologists are right in calling it philosophically naive and confused, and yet it is a much better guide for practicing economists than its two main rivals, a priorism, and naive empiricism. A second reason is its persuasive style which presents seemingly audacious, and hence stimulating, statements with an air of sweet reasonableness. Third there are Friedman's achievements in substantive economics, often grounded in a methodology which, if not exactly that of F53, bears a reasonably close relation to it. Whether the association of F53 with the marginalist controversy, helped or hindered is hard to say. Marginalists had a strong incentive to welcome F53. But institutionalists could dismiss it as "enemy propaganda" without appreciating the large olive branch of its opposition to walrasian economics. Friedman's political views may also have induced some economists to oppose F53. But I suspect that this was only a minor factor. Finally, Friedman's personality for some reason, seems to provoke either ardent admiration or sharp opposition; the net effect of that is hard to gauge.

\section{CONCLUSION}

Since 1953 economics has changed along the lines F53 recommended. However, other factors could also have accounted for these changes, particularly for the shift away from testing by the realisticness of assumptions. At the same time, some of these factors could also explain why Friedman seems to have failed in his opposition to walrasian economics. But it is possible that without F53 the walrasian tide might have been stronger, so that even on this issue F53 may have been influential. 
How much of the observed changes in economics one attributes to F53 and how much to these other factors depends, in part, on one's acceptance of the Stiglerian and postmodernist view that economists' theory choice is governed by their self-interest. But even if it is, F53 could still have been influential by providing a convenient rationalization for, and thus accelerating, the changes that occurred. To what extent it did so is a matter of intuitive appraisal more than of solid evidence, and I feel qualified to make such an appraisal only with respect to macroeconomics. Although the immediate inspiration for and the examples given in F53 are microeconomic, F53 seems to have been more influential in macroeconomics since so much of modern microeconomics consists of building models that explore the implications of different assumptions (See also Williamson's paper in this volume.) Perhaps F53's greater influence on macroeconomics is due, in part, to Friedman's own shift of emphasis towards macroeconomics, or to macroeconomics being traditionally more policy oriented, and hence more aware of the need for a Marshallian approach and for correct predictions. Within macroeconomics F53 probably played an important - perhaps a very important - role in the ready acceptance of the LCH, PIT and the rational-expectations consumption function. And it did play a major role in the monetarist counter-revolution, and in that way in the synthesis of monetarism and new Keynesianism that underlies the currently prevailing macroeconomics. Eventually the hard facts of experience would have prevailed over the Keynesianism of the 1960s and 1970s even without F53, but it would have taken them considerably longer. And perhaps new classical theory, too, would not have made the big time were it not for F53's warnings against testing by the realisticness of assumptions, and against reliance on casual empiricism. It is even possible that this was the most important influence of F53. That would be ironic. 
In microeconomics I suspect, but that may just reflect my lack of familiarity with it, that F53 did influence primarily Chicago economists, and perhaps work on public choice theory. But by its stress on the explanation of specific phenomena it may also (probably indirectly) have influenced work on asymmetric information. 


\section{APPENDIX A - GAME THEORY}

Game theory has replaced much of Chicago price theory. Has it done so in concert with, or in the teeth of, F53? The answer depends on which game theorist one reads. Robert Aumann approaches game theory in a Friedmanian way, putting great emphasis on empirical applications. Thus, he judges a solution concept: "more by what it does than by what it is" (Aumann, 1985, p. 28), by how well it performs in applications. "Empirics are vital" (Aumann in van Damme, 1998, p. 189). Although Aumann places comprehension ahead of prediction, he treats prediction as an "excellent" way of testing theories (Aumann, 1985, p. 29). He defends the validity of the utilitymaximization assumption as an organizing theory, even though individuals do not really maximize utility. "I have never been so interested in assumptions. I am interested in conclusions. Assumptions don't have to be correct" (Aumann, in van Damme 1998, p. 200). Aumann is also strongly Marshallian and cites many applications of game theory to important real-world problems, and writes about Shapley values: "this theory may well be mathematically the richest and deepest in game theory. Of course, this is intellectually pleasing, but that is not where its importance lies. Its importance lies in the fact that this theory enables us to deal with the applications, to attack fairly complex models in a systematic manner and to solve them." (Aumann, 1985, p. 64) He does not seem to favor casual empiricism: the empirical successes he mentions are well documented. He does, however, disagree with Friedman by believing that one cannot clearly separate normative from positive theory. Finally, his work shows a continual interaction between theorizing and testing the applications of the theory.

Reinhard Selten (1985, p. 77) calls experimental research of "crucial importance" in making game theory more descriptive (by which he seems to mean applicable), though he also believes that it is important to work out the pure logic of rational decision theory. Unlike Aumann he 
agrees with Friedman on the possibility of drawing a sharp distinction between normative and positive economics, He is also Marshallian in wanting to discover how the economy actually functions rather than just the logical implications of rational maximizing behavior.

In other hands game theory is much less Friedmanian, being concerned more with rigorous derivations than with empirical relevance. Thus, Ariel Rubinstein is "not thrilled" that many people view game theory as "useful", and he does not consider applicability to be a "necessary virtue". (Rubinstein, 2000, pp. 71, 73). But he, too, agrees that effective game theory models require "intuition, common sense and empirical data" to determine what factors to include in the model (Rubinstein, 1991, p. 919). John Sutton (1990) believes that in work on industrial economics game theory has shifted attention away from the empirical emphasis of the 1960s and 1970s. Taking a Friedmanian approach he is uneasy about the multiplicity of solutions and lack of robustness so common in game theory. Similarly, Sushil Bikhchandani (1993) has remarked that game theory models are usually not tested empirically, though within the subfield of auction theory greater empirical testing has started.

A telling question, but one which an outsider like I cannot answer, is how game theorists feel when they read a sophisticated proof that a certain model has multiple solutions. Are they disappointed? Or are they pleased that game theory has been enriched by one more sophisticated proof?

\section{APPENDIX B - NOBEL PRIZE LECTURES}

Jan Tinbergen's (1992) lecture deals with the current usefulness of econometric models and their future development. He states that common sense must be used in their construction, which suggests a predilection towards realistic assumptions but, (though he refers to it only briefly) predictive success is obviously the main criterion for an econometric model. Tinbergen's 
emphasis on the need to incorporate detailed information in models is Marshallian. Model builders may, of course, use introspection and casual empiricism in formulating some of the equations of the model, but the ultimate test of the model is hard empiricism. There is a continual interplay of theory and testing.

Paul Samuelson (1992) devoted his lecture to describing the usefulness of the maximizing principle and mathematical economics in general. It is therefore orthogonal to F53. However, elsewhere Samuelson (1963) strongly disagrees with Friedman's claim that hypotheses should be tested by the accuracy of their predictions and not by the realisticness of their assumptions. Kenneth Arrow's (1992) lecture describes the development of general equilibrium theory, and thus is walrasian. It shows a mathematician's concern with minimizing assumptions, which, while not necessarily inconsistent with F53 points in a different direction. Arrow also provides some rather casual discussion of the empirical relevance of the assumptions. His paper can be read as contrary to F53.

In his lecture Wassily Leontief (1992) applies input-output analysis to the world economy. For this the obvious test is predictive accuracy, though the lecture does not discuss any tests of inputoutput models. Such a model is walrasian in the sense that it encompasses the whole economy, but is Marshallian in the here more relevant sense of being concerned with empirical observations and practical applications more than with elegant theory. Casual empiricism has a role in this analysis only to the extent that it is forced on the researcher by the paucity of data, and is obviously something to be minimized. There is interplay between theoretical and empirical work in the sense that the theoretical framework used, e.g. the number of separate industries, has to be adapted to the availability of data. 
Friedrich Hayek's (1992) lecture is strongly anti-F53 since he believes that the techniques of the natural sciences cannot be fruitfully applied to the more complex problems of the social sciences. Their theories cannot be properly tested by predictions. Moreover, Hayek shows sympathy for a mathematical economics that is divorced from empiricism and is therefore in line with walrasian economics. Since, in general, Hayek rejects the use of statistics in economics, there is no question about the interplay of theory and data, at least the way economists generally interpreted data as statistics.

On the surface Herbert Simon's (1979) lecture is contrary to F53 since he writes: "I cannot in this brief space mention ... all of the numerous logical fallacies that can be found in..." it (Simon, 1979, p. 495n.) And yet the lecture is Friedmanian, at least if F53 is given a soft reading.(Cf. Mayer 1993). Yes, Simon does advocate testing by the realisticness of assumptions, but that is consistent with F53 if these assumptions can also be treated as implications, and Simon does use tests of implications. On the other issues his lecture seems consistent with F53 in that Simon is Marshallian, relies on serious empiricism, and seems to imply an interplay of data analysis with theorizing. Simon's quarrel is much less with Friedman's methodology than with the implication that Friedman draws from it, that the neo-classical theory of the firm is alive and well. Theodore Schultz's (1980) lecture deals with agriculture in developing countries and the motivation of and incentives faced by farmers. It is Marshallian in its close attention to empirical research. In this way it avoids casual empiricism, and shows an interplay of observation and theorizing. While the choice between testing by assumption and testing by prediction is not explicit, the general tenor of the paper gives the impression that Schultz would test hypotheses primarily by their predictive success. 
Debreu presents in his lecture primarily an exposition and history of mathematical economics, and a discussion of the virtues of axiomization. It points economics in a direction very different from F53. Thus, being normative it sets out strategies that players can follow without asking if players actually do follow them. Hence, the realisticness of assumptions is not relevant. It is walrasian in the sense of trying to build a rigorous model from certain premises, rather than explaining any actually observed behavior. Casual empiricism and the interplay of theory and data are not relevant issues because there is no empiricism of any kind.

In his lecture James Buchanan interacts with Friedman's essay on only a few points, perhaps because it is short and concentrates on only a few fundamental issues that underlie the publicchoice paradigm for which he received the prize. All the same, there is concordance. He is clearly Marshallian rather than walrasian in his focus on practical problems and on the importance of institutional "detail". There is little empirical work, either casual or serious in his lecture, but the school he founded and its journal place much emphasis on an empiricism that is far from casual. And introspection probably plays a much smaller role in his analysis than it does in that of the philosophers and political theorists who have wrestled with the problems he tackles. And while the interplay of theory and data does not have a role in this theoretical paper, it may well do so in the empirical literature of his school.

Robert Solow's lecture provides a good example of Friedmanian methodology. While Solow mentions that his work originated in his discomfort with the assumptions of the prevailing Harrod- Domar growth models that the savings rate, the capital/output ratio and the growth rate of the labor force are all exogenous, this should be interpreted as dissatisfaction with a lack of generality rather than with a lack of realisticness, since Solow (1988, p. 314) states that "every piece of empirical economics rests on a substructure of background assumptions that are 
probably not quite true." Moreover, he also complains that the Harrod-Domar models incorrectly predict great instability. His Marshallian credentials become apparent in his criticism of new classical theory, and serious empiricism is evident in his lecture. And he describes an interaction of empirical and theoretical elements in the development of his models.

Maurice Allais (1997) states his methodological principles explicitly in his lecture. These have much in common with F53. Thus he insists on testing theories by their predictive success, and does not even mention tests by the realisticness of assumptions. Despite his extensive use of mathematical models he rejects what Friedman calls walrasian economics, writing: "Any theory, whatever, if it is not verified by empirical evidence has no scientific value and should be rejected." (Allais, 1997, p. 7) And while his lecture does not directly refer to casual empiricism, it gives the impression that this is unacceptable. He does not tell us how theory and observation interact in his work.

While brief and general Trygve Haavelmo's (1997) lecture suggests a methodology that is close to F53. Since he deals with econometrics he implicitly supports evaluating theories by their predictive success, and while he does not explicitly refer to testing by the realisticness of assumptions, it is highly unlikely that he prefers this to testing by predictive results. In his emphasis on testing he is Marshallian, and as an econometrician he is hardly likely to favor casual empiricisms and introspection. One cannot tell whether he favors continual interplay between theorizing and observing.

Although he does not mention it in his Nobel lecture Ronald Coase rejects Friedman's focus on predictive success as the criterion for theory choice; to him explanatory power is more important. His emphasis on just how markets function makes his work Marshallian, and it 
embodies serious rather than casual empiricism. It gives the impression of a continual interplay of data and theory.

Not surprisingly Gary Beckers' (1993) lecture is in the spirit of F53. It is full of references to empirical papers that confirm implications of his hypothesis. He is a Marshallian and a believer in the interplay of theory and data. ${ }^{20}$ His focus on empirical evidence frees him from reliance on casual empiricism.

Douglass North's (1994) lecture is Friedmanian in those aspects that matter, despite his talking about some assumptions of neo-classical theory, and of modifying the rationality assumption. The seeming disagreement with F53 is superficial since he criticizes the rationality assumption of neoclassical theory, not because it is unrealistic, but because it may create obstacles to prediction and explanation; It may be useful in the case of modern market economies, but not elsewhere. Thus. the realisticness of this assumption determines the reach rather than the validity of a theory. North's work is clearly Marshallian. He emphasizes transaction costs and the special nature of markets that operate efficiently. North being an economic historian, his empiricism is far from casual. Finally, North is Friedmanian in his interplay of theory and observation. By contrast John Harsanyi's (1995) lecture is entirely unrelated to F53. It is normative since it sets out strategies that players can follow without asking if they actually follow them. Hence, realisticness of assumptions is not relevant. It is walrasian in the sense of trying to build a rigorous model from certain premises, rather than explaining any actually observed behavior. Casual empiricism is not an issue because there is no empiricism of either kind. Also, there is no interaction between observation and theorizing since the former element is not there. James Mirrlees' (1997) lecture deals with optimal taxation in the presence of asymmetric information. This is a normative issue where the question of whether to test by the realisticness 
of assumptions or the accuracy of predictions does not arise. Mirrlees' model should probably be classified walrasian rather than Marshallian. Given the stage of development of such a model its casual empiricism does not raise an important issue.

Myron Scholes' (1998) very different Nobel lecture concords with F53. He describes a formula for pricing derivatives, e.g., stock options, and does not worry about the assumptions it requires, such as fully efficient markets, being realistic. Instead he evaluates the success of his formula by testing the success of a trading strategy that it implies. He is Marshallian in that he pays attention to institutional detail and real-world problems, and makes no use of casual empiricism or introspection. Scholes' description of his work shows him going back and forth between theory and data.

Amartya Sen's (1999) lecture owes nothing to F53 because it deals with a type of problem, social choice theory, that, by and large, does not lend itself to the prescriptions of F53 In his lecture Daniel McFadden (2001) describes developments in consumer choice theory and in the econometric techniques used to apply and test it. It is consistent with F53. Consumer choice theory can be testing by its predictions and McFadden gives an example of such a test. While he accepts as valid the various problems that psychologists have found with the realisticness of the assumptions of this theory, he concludes that "the standard model enhanced to account for the most systematic perceptual illusions will prove to be the best platform for evaluating most economic policies." (2001, p. 363,) His belief that economists have much to learn from the work of market researchers illustrates his adherence to Marshallian methodology. His lecture is full of serious as opposed to casual empiricism, and the interplay of theory development and empirical testing is evident. 
At first glance George Akerlof's lecture seems anti-F53 since the motivation for his work is to strengthen macroeconomics by introducing more realistic assumptions. But that does not necessarily mean that theories should be evaluated by the realisticness of their assumptions. It could be that he thinks these more realistic assumptions are necessary for predictive success. Thus, he writes that the behavioral assumptions of the new classical model are so primitive that it "faced extreme difficulty in accounting for at least six macroeconomic phenomena" (Akerlof, 2002, p. 412) while his model can account for them. Moreover, as Sugden, 2002) points out in his basic ("Lemons") paper Akerlof acknowledges that his assumptions are not realistic. He describes his work as an orientation that pays careful attention to "realistic microeconomic detail" (Akerlof, 2002, p. 414), which makes him a Marshallian. Casual empiricism does show up in his basic "Lemons" paper (see Sugden, 2002), but in his lecture he cites many detailed empirical studies. There are strong suggestions of the interplay of observation and theory. Vernon Smith's (2003) lecture is in the spirit of F53, though it bears little resemblance to Friedman's version of microeconomic theory. While it contains no explicit statements about testing by predictions vs. testing by assumptions the tests that Smith offers are predictive tests, though admittedly somewhat unusual ones from the viewpoint of mainstream economics. In particular, he shows that the assumption of rational behavior by individuals is not needed to generate market equilibrium, His approach is Marshallian in valuing agreement with observations over elegance, and he relies on a wide variety of serious empirical evidence, Some of this is from surveys, but these surveys are far different from the naive surveys that Friedman criticized, His lecture shows a continual interplay of empirical work and theory, which may, but of course need not, reflect the way he works. 


\section{REFERENCES}

Akerlof, George (2002) "Behavioral Macroeconomics and Macroeconomic Behavior," American Economic Review, 92, September, 411-33

Allais, Maurice (1997) "An Outline of my Main Contribution to Economic Science," American Economic Review, 87, December 1997, 3-12

Allen, Clark (1954) Review of Milton Friedman Essays in Positive Economics, $\underline{\text { Southern }}$ Economic Journal,. 10, January, 394-9.

Arrow, Kenneth (1992) "General Economic Equilibrium: Purpose, Analytic Techniques, Collective Choice," in Assar Lindbeck, Nobel Lectures, Economic Sciences, 1969-1980, Singapore, World Scientific,

Aumann, Robert (1985) "What is Game Theory Trying to Accomplish?" in Kenneth Arrow and Seppo Honkapohja, Frontiers of Economics, Oxford, Basil Blackwell.

Backhouse, Roger, (2002) "Economic Models and the Role of Informal Scientific Methods," in Uskali Mäki, Fact and Fiction in Economics, New York, Cambridge University Press, 202-13

Baumol, William (1954) Review of Milton Friedman Essays in Positive Economics, Review of Economics and Statistics, 36, November, 462-65

Becker, Gary (1993) "Nobel Lecture: The Economic Way of Looking at Behavior," Journal of Political Economy, 101, June, 385-409

Blaug, Mark (1980) The Methodology of Economics Cambridge, Cambridge University Press.

Boulier, Brian and Goldfarb, Robert (1998) "On the Use and Nonuse of Surveys in Economics," Journal of Economic Methodology, 5, June, 1-22.

Brunner, Karl (1969) " 'Assumptions' and the Cognitive Quality of Theories," Synthese, 20, 501-25.

Colander, David (1991) "The Lost Art of Economics," Journal of Economic Perspectives, 6, Summer, 191-98.

Dasgupta, Partha, "Modern Economics and its Critics:, Fact and Fiction in Economics, Cambridge, Cambridge University, 57-89.

Duesenberry, James (1949) Income, Saving and the Theory of Consumer Behavior, Cambridge, MA, Harvard University Press

Figlio, David (1994) "Trends in the Publication of Empirical Econom ics", Journal of Economic Perspectives, 4, Summer, 179-187 
Friedman, Milton (1949) "Discussion," American Economic Review, 39, May, 196-99.

Friedman, Milton (1950) "Wesley C. Mitchell as an Economic Theorist", Journal of Political Economy, 58 (December) 463-95.

Friedman, Milton (1953) Essays in Positive Economics, Chicago, University of Chicago Press.

Friedman, Milton (1957) A Theory of the Consumption Function, Princeton, Princeton University Press

Friedman, Milton and Kuznets, Simon (1945) Income from Independent Professional Practices, New York, National Bureau of Economic Research.

Friedman, Milton and Schwartz, Ann 1963) A Monetary History of the United States, Princeton, Princeton University Press.

Lerner, Abba (1944) The Economics of Control, London, MacMillan

Gurley, Jack and Shaw, Edward (1960) Money in a Theory of Finance,, Washington, DC, Brookings.

Hahn, Frank (1971) "Professor Friedman's Views on Money," Economica N.S., 39, February, 61-80.

Hahn, Frank and Matthews, Robin (1964) "The Theory of Economic Growth: A Survey," Economic Journal, 74, December , 779-902

Hammond, Daniel (1990) "McCloskey's Modernism and Friedman's Methodology: A Case Study with New Evidence," Review of Social Economy, 48, Summer, 158-71.

Hammond, Daniel (1996) Theory and Measurement, Cambridge, Cambridge University Press.

Hammond, Daniel (1998) "Friedman, Milton" in J. Davis, D.W. Hands and U. Mäki, Handbook of Economic Methodology, Cheltenham, Edward Elgar.

Harsanyi, John (1995) "Games with Incomplete Information," American Economic Review, 85, June, 291-393

Haavelmo, Trygve (1997) "Econometrics and the Welfare State," American Economic Review, 87, December, 13-15

Hayek, Friedrich von (1992) "The Pretence of Knowledge," in Assar Lindbeck, Nobel Lectures, Economic Sciences, 1969-1980, Singapore, World Scientific, 
Hirsch, Abraham and de Marchi, Neil (1990) Milton Friedman, New York, Harvester Wheatsheaf

Hoover, Kevin (2001) The Methodology of Empirical Macroeconomics, Cambridge, Cambridge University Press

Hoover, Kevin (2003) "Lost Causes", unpublished manuscript.

Hoover, Kevin and Perez, Stephen (2000) "Three Attitudes Towards Data Mining," Journal of Economic Methodology, 7, June, 195-210.

Hutchison, Terence (1954) Review of Milton Friedman Essays in Positive Economics, Economic Journal, 64, December, 796-99.

Keynes, John. M. (1936) The General Theory of Employment, Interest and Money, New York, Prentice Hall.

Keynes, John N. (1963) The Scope and Method of Political Economy, New York, Augustus Kelly

Klein, Lawrence (1950) Economic Fluctuations in the United States, 1921-1941,, John Wiley.

Leontief, Wassily (1992) "Structure of the World Economy," in Assar Lindbeck (ed.) Nobel Lectures, Economic Sciences, 1969-1980, Singapore, World Scientific,

Mayer, Thomas (1993) "Friedman's Methodology of Positive Economics: A Soft Reading," Economic Inquiry. 31, April, 213-23.

Mayer, Thomas (1995) Doing Economics, Cheltenham, Edward Elgar.

McFadden, Daniel (2001) "Economic Choices," American Economic Review, 91, June, 351-78.

Mirrles, James (1997) "Information and Incentives: The Economics of Carrots and Sticks," Economic Journal, 107, September, 1311-29

Modigliani, Franco (2001) Adventures of an Economist, New York, Texere.

Musgrave, Alan (1981) "Unrealistic Assumptions in Economic Theory," Kyklos, 34, (3) 377-87.

Newman, Peter (1954) Review of Milton Friedman Essays in Positive Economics, Economica, 21, August, 259-60.

North, Douglass (1994) "Economic Performance Through Time," American Economic Review, 84, June, 359-68 
Reder, Melvin (1982) "Chicago Economics: Permanence and Change", Journal of Economic Literature, 20, March, 1-38

Rubinstein, Ariel (1991) "Comments on the Interpretation of Game Theory," Econometrica, 59, July, 909-24.

Rubinstein, Ariel (2000) Economics and Language, Cambridge, Cambridge University Press.

Samuelson, Paul (1992) "Maximum Principles in Analytical Economics," in Assar Lindbeck (ed.) Nobel Lectures, Economic Sciences, 1969-1980, Singapore, World Scientific,

Schneider, Erich (1955) Review of Milton Friedman Essays in Positive Economics, Weltwirtschaftliches Archiv.

Scholes, Michael (1998) "Derivatives in a Dynamic Environment," American Economic Review, 88, June, 350-70

Schultz, Theodore (1980) "Nobel Lecture: The Economics of Being Poor," Journal of Political Economy, 88, \# 4, 639-51

Selten, Reinhard (1985) "Comment," in Kenneth Arrow and Seppo Honkapohja, Frontiers of Economics, Oxford, Basil Blackwell.

Sen, Amartya (1999) "The Possibility of Social Choice," American Economic Review, 89, June, 349-78.

Simon, Herbert (1979) "Rational Decision-making in Business Organizations," in Assar Lindbeck (ed.) Nobel Lectures, Economic Sciences, 1969-1980, Singapore, World Scientific.

Smith, Vernon (2003) "Constructionist and Ecological Rationality in Economics," American Economic Review, 93, June, 465-508.

Snowdon, Brian and Vane, Howard (1999) Conversations with Leading Economists, Cheltenham, England, Edward Elgar.

Solow, Robert (1988) "Growth Theory and After," American Economic Review, 78, June, 307 17.

Soper, C.S. (1954) Review of Milton Friedman Essays in Positive Economics, Economic Record, 30, November, 323-26

Sugden, Robert (2002) "Credible Worlds: The Status of Theoretical Models," in U. Mäki, Fact and Fiction in Economics, Cambridge, Cambridge University Press.

Sutton, John (1990) "Explaining Everything, Explaining Nothing," European Economic Review, 34, 505-12. 
Tinbergen, Jan (1992) "The Use of Models: Experience and Prospects," in Assar Lindbeck (ed.) Nobel Lectures, Economic Sciences, 1969-1980, Singapore, World Scientific,

van Damme (1998) "On the State of the Art in Game Theory: An Interview with Robert Aumann", Games and Economic Behavior, 34, 161-210

Vickrey, William (1954) Review of Milton Friedman Essays in Positive Economics, American Economic Review, v 44, June, 397-400

Waldman, Michael (2003) "Durable Goods Theory for Real World Markets," Journal of Economic Perspectives, 17, Winter, 2003. 131-54.

\section{ENDNOTES}

* I am indebted for helpful comments to Daniel Hammond, Uskali Mäki and Klaus Nehring.

1. Partha Dasgypta (1993, p. 57) remarked that he knows "no contemporary practicing economist whose investigations have been aided by the writings of professional methodologists."

2. I do not consider the number of citations to F53 in the Social Science Citation Index (SSCI). On the one hand, citation counts may understate a paper's influence, since its influence may be indirect via another paper that is cited instead of the original source. Indeed, once an idea becomes well-known, it no longer requires citation. Moreover, a paper may exert a strong negating influence that does not generate a single citation: no citation appears if F53 prevented an economist from writing a paper criticizing a theory for its unrealistic assumptions. It is even possible for a paper's influence to be inversely related to the frequency of its citations. If it criticizes a research program convincingly it may terminate work on that topic and therefore not be cited. Another problem is that the SSCI ignores citations in books. On the other hand, a citation count may overstate a paper's influence. Many citations are just hat-tipping references, made to show that the author is familiar with the paper, or they may be from a paper that criticizes it. Moreover, an economist may cite F53 as a justification for an unrealistic assumption she would have made in any case.

3. Hirsch and de Marchi (1990, pp. 154-59) in discussing both Friedman's methodological writings and his practices categorize his themes somewhat differently as: (1)" adopt an outside view" that is, reject arguments from introspection; (2) begin with observations; (3) continually test the implications of hypotheses, though not in a falsificationist mode; (4) base empirical tests on the framework of the most reliable available knowledge; and (5) focus on concrete problems. Perhaps because I deal with F53 and not with Friedman's own methodological practice I am using a different framework.

4. Not all the stated assumptions of a theory are necessary assumptions, some are expository assumptions, or domain-defining assumptions, etc., (see Musgrave 1981). Moreover, the necessary assumptions may be stated more broadly than is required. A way to determine whether 
an assumption is a necessary one and stated no more broadly than required, is to see if it can also be stated as an implication. But what about a theory's power to explain? Friedman surely consid ered explanation in the sense of subsuming an observation (or a narrow theory) into a (broader) theory to be important - his reference to generality, and his substantive work both before and after 1953 bear witness to that -- as does his teaching price theory. To Friedman generality, and thus explanation, is important, but the acid test is prediction.

5. Friedman, like many economists of his generation, became an economist because of the suffering he saw during the Great Depression (see Snowdon and Vane, 1999, pp. 124-5.) That may explain his emphasis on practicality.

6. Hirsch and de Marchi (1990, p. 19) argue that it is Friedman's rejection of introspection that distinguishes his methodology from the traditional one. They also call confidence in introspection "undoubtedly a major reason that methodologists argue on the basis of 'realistic' assumptions," (p. 56)

7. An example of this is the treatment of Gurley and Shaw's Money in a Theory of Finance (1960). It was savaged when it appeared, but over the years some of its ideas became influential without acknowledgments.

8. Some assumptions, such as rational behavior, are hard to formulate as testable hypotheses, and many others, such as a closed economy, are obviously not intended to be realistic, and hence not something anyone would want to test.

9. They did, however, also facilitate the use of questionnaires, but probably not by as much as time-series data, particularly since they did not reduce the cost of interviewing or mailing and editing surveys.

10. At the time both the Journal of Political Economy and the American Economic Review reviewed books, The Journal of Economic Literature not yet having appeared. The Journal of the American Statistical Association reviewed some economics books, but not this one.

11. Hoover and Perez (2000) argue that data mining is necessary because most hypotheses cannot be specified so precisely that a single test suffices. Yes, data mining may be necessary, but it still reduces the credibility of empirical tests.

12. Such a short review was unusual for this journal, but in the same issue Schneider also reviewed in just two paragraphs the second edition of Michael Kalecki's Theory of Economic Dynamics.

13. The discussion of surveys in F53 is perfunctory, But in a paper cited in F53 Friedman (1949) had set out his criticisms of surveys that ask agents to reveal their motives or thinking. There he did not criticize surveys of factual information, indeed he himself (Friedman and Kuznets, 1945) had used such evidence. As Boulier and Goldfarb (1998) show, survey information now 
pervades empirical economics, but most of it comes from objective questions, not ones about opinions and motives,

14. These six are: Kantorovich, Kutznets, Meade, Miller, Stigler, and Stone.

15. I exclude the normative/positive distinction because economics has changed little in that respect.

16. Modigliani and Ando developed the theory initially like a "ray of light" while on a car trip. Although Modigliani in developing the relative income theory had previously analyzed consumption data, he had then "neglected the problem" until his conversation with Ando. (Modigliani, 2001, p. 59)

17. Predictive success is, however, not the only important criterion. Even if it predicts accurately we would reject a theory that explains the U.S. price level by the league standing of Manchester United. Friedman himself rejects large econometric models because he believes that they require much more knowledge than we have.

18. Brunner's (1969) view on the role of assumptions was similar to Friedman's

19. That expenditures depend more on the incentives to spend than on money holdings seems obvious to middle class people (such as most economists) who think of expenditures primarily as consumption. It may not be so obvious to the rich who are busy with asset reallocation, or to the poor who are severely cash constrained. From the late 1930s to the early 1950s Keynesians attached much importance to speculative liquidity preference without any evidence that it is empirically significant. The issue of plausibility of assumptions vs. accuracy of predictions also plays an important role in disputes about monetary policy. Until the application of timeinconsistency theory one of the two central points in this debate was the Keynesian argument that one can infer from the plausible assumption that central bankers are well intentioned and intelligent, that they will pursue reasonable policies. Monetarists responded by citing instances of perverse policy, that is instances where the Keynesian theory predicted badly.

20. Thus he wrote:

None of the theories considered in this lecture aims for the greatest generality; instead, each tries to derive concrete implications about behavior that can be tested with survey and other data. ... A close relation between theory and empirical testing helps prevent both the theoretical analysis and the empirical research from becoming sterile. Empirically oriented theories encourage the development of new sources and types of data ... [P]uzzling empirical results force changes in theory (Becker, 1993, pp. 402-403)

His reference to the use of "surveys" does not contradict F53 since these surveys may deal with objectively measured attributes rather than opinions. 
Table 1

Effect of Changes in Economics on the Acceptance of F53

$\begin{array}{lllll}\text { Mathemat- } & \text { Computers, Increased } & \text { Greater } & \text { Prestige } & \text { Quality } \\ \text { ization } & \text { econometrics, resources } & \text { policy } & \text { of } & \text { of } \\ & \text { data } & \text { role } & \text { Chicago } & \text { Economists }\end{array}$

Assumptions

vs. predictions

$+{ }^{a}$

$+$

$+$

$+$

$+$

?

Marshallian

vs. Walrasian

$+$

?

$+$

$+$

?

Casual

Empiricism,

Introspection

- ?

$+$

$+$

? +

?

Theory/data

Interaction

$-?$

?

$?$

$+$

$+$

?

NOTE: + denotes influence in the direction of F53, - denotes influence in the opposite direction, ? denotes direction unknown and a superscripted ? some doubt the direction.

a. Likely, but not certain direction. 
Table 2

The Nobel Prize Lectures and Friedman's Criteria ${ }^{\mathrm{a}}$

\begin{tabular}{|c|c|c|c|c|}
\hline $\begin{array}{l}\text { Author } \\
\text { and date }\end{array}$ & $\begin{array}{l}\text { Assumptions } \\
\text { s. predictions }\end{array}$ & $\begin{array}{l}\text { Marshallian/ } \\
\text { Walrasian }\end{array}$ & $\begin{array}{l}\text { Casual } \\
\text { empir- } \\
\text { icism }\end{array}$ & $\begin{array}{l}\text { Interplay of } \\
\text { theory and } \\
\text { data }\end{array}$ \\
\hline Tinbergen, 1969 & + & + & + & + \\
\hline Samuelson, 1970 & $-b$ & 0 & 0 & 0 \\
\hline Arrow, 1972 & $0^{\mathrm{c}}$ & - & 0 & 0 \\
\hline Leontief, 1973 & + & $+c$ & + & + \\
\hline Hayek, 1974 & - & - & $-e$ & - \\
\hline Kantorovich, 1975 & 0 & 0 & 0 & 0 \\
\hline Simon, 1978 & $?^{\mathrm{f}}$ & + & + & + \\
\hline Shultz. 1979 & $+\mathrm{g}$ & + & + & + \\
\hline Debreu, 1983 & 0 & - & $\mathrm{O}^{\mathrm{h}}$ & - \\
\hline Buchanan , 1986 & 0 & + & $+\mathrm{i}$ & $?^{\mathrm{j}}$ \\
\hline Solow, 1987 & + & + & + & + \\
\hline Allais, 1988 & + & + & + & 0 \\
\hline Haavelmo, 1989 & + & + & + & 0 \\
\hline Coase, 1991 & $-\mathrm{k}$ & + & + & + \\
\hline Becker, 1992 & + & + & + & + \\
\hline North, 1993 & + & + & + & + \\
\hline Harsanyi, 1994 & 0 & + & 0 & 0 \\
\hline Mirrlees, 1996 & 0 & - & $0^{1}$ & 0 \\
\hline Scholes, 1997 & + & + & + & + \\
\hline Sen, 1998 & 0 & 0 & 0 & 0 \\
\hline McFadden, 2000 & + & + & + & + \\
\hline Akerlof, 2001 & ? & + & + & + \\
\hline Smith, 2002 & $+\mathrm{m}$ & + & + & + \\
\hline
\end{tabular}

Note: + denotes consistent with F53, - denotes inconsistent with F53, 0 unrelated to F53 with respect to that criterion, and ? hard to say.

a. This table does not cover all Nobel lectures, For the reasons some were excluded see text,

b. Samuelson does not discuss this issue in his lecture, but has elsewhere strongly rejected Friedman's stricture against testing by the realism of assumption.

c, Arrow’s advocacy of minimizing assumptions is consistent with Friedman’s position,

d, Leontief uses a general equilibrium model, but is Marshallian in paying attention to the details of specific industries,

e, This is not explicit in Hayek's lecture, but is inherent in his general position, 
f. In his essay Simon strongly criticizes Friedman's essay, but the substance of his essay is consistent with it, at least if it is given a soft reading,

g. Based on the general tenor of his lecture rather than on an explicit statement,

h, No empiricism of any kind

i, There is little empiricism in his essay, but it plays a large role in the work of his school,

$\mathrm{j}$, No data are discussed in his essay, but in the work of his school there may well be an interplay of theory and data,

k. Coase does not criticize Friedman on this score on this essay, but does so elsewhere,

1. There is casual empiricism, but at this stage of the development of the model one cannot except anything more.

m. By implication. 